\title{
Teikoplaninin indüklediği nöbet
}

Teicoplanin induced seizure

\author{
Bayram Yeşil Mustafa Kaplan Orhan Coşkun Volkan Gökbulut \\ Ferhat Bacaksız Erkin Öztaş Ertuğrul Kayaçetin \\ Türkiye Yüksek İhtisas Eğitim ve Araştırma Hastanesi, Gastroenteroloji Kliniği, Ankara, Türkiye
}

\section{Öz}

Elli altı yaşında erkek hasta karaciğer nakli sonrası anastomoz darlığı ve kolanjit tanısı ile kliniğimize başvurdu. Hastaya perkütan transhepatik kolanjiografi (PTK) yapıldı. Kolanjit tanısı ile imipenem başlandı. Ancak ateş ve beyaz küre değerinde yükseklik olması üzerine imipenem tedavisinin 10. gününde teikoplanin eklendi. İlaç başlandıktan bir gün sonra tonik klonik epileptik nöbetleri oldu. Kranial bilgisayarlı tomografi (BT), elektroensefalografi (EEG) ve kranial magnetik rezonans görüntüleme (MRG) çekildi. Sadece MRG'de kronik iskemik değişiklikler saptandı. Laboratuvar analizinde kan sodyum $124 \mathrm{mEq} / \mathrm{L}$ saptanan hastaya replasman tedavisi yapıldı. Hastaya levetiracetam başlandı. Epileptik atakları tekrarlayan hastada metabolik asidoz gelişti ve entübe edildi. Teikoplanin verilmesinden hemen sonra başlaması ve diğer etiyolojik faktörlerin dışlanması nedeniyle nöbetlerin teikoplanine bağlı olabileceği düşünüldü ve hastanın ilacı kesildi. İlaç kesilmesi sonrası nöbetler kesildi. Ancak ventilatöre bağlı pnömoni gelişen hasta exitus oldu. Enfekte ve teikoplanin alan bir hastada nöbet varlığında ilaca bağlı nöbet akılda tutulmalıdır.

Anahtar Sözcükler: Epilepsi, metisilin dirençli staphylococcus aureus (MRSA), teikoplanin.

\begin{abstract}
Fifty six years old male patient admitted to our clinic with cholangitis due to anastomosis stricture after liver transplantation. Percutaneous transhepatic cholangiography (PTK) was performed and imipenem was started. Teicoplanin was added to treatment at 10th day because of fewer and elevated WBC. Tonic clonic epileptic seizures was developed 1 day after the teicoplanin was started. Cranial CT, MRI and EEG is performed. Only chronic ischemic changes was seen in MRI. At laboratory analysis, serum sodium level was $124 \mathrm{mEq} / \mathrm{L}$ and was corrected. Levetiracetam was started. The patient was entubated because of metabolic asidosis due to repeated epileptic seizures. Because of seizures started after teikoplanin and that we could not find any etiologic factor, we thought that seizure was induced by teicoplain. The drug was stopped and seizures ended. But the patient died due to ventilator associated pneumonia. Teicoplanin induced seizure must be kept in mind in infected patients with seizures.
\end{abstract}

Keywords: Epilepsy, meticilline resistant staphylococcus aureus (MRSA), teicoplanin.

\section{Giriş}

Epileptik nöbet, beyin disfonksiyonu sonucu ortaya çıkan ani bir davranış değişikliği olarak tanımlanabilir ve nöbetler serebral kortekste nöronal ağların elektriksel aşırı aktivitesinden kaynaklanır, etiyolojide ilaçlarında içinde bulunduğu birçok faktör yer almaktadır. Teikoplanin metisilin dirençli staphylococcus aureus (MRSA) ve enterococcus faecalis dahil gram-pozitif bakterilere bağlı ciddi enfeksiyonların tedavi ve profilaksisinde kullanılan, vankomisine benzer spektrumda semisentetik glikopeptid antibiyotiktir.

Yazışma Adresi: Bayram Yeşil

Türkiye Yüksek İhtisas Eğitim ve Araştırma Hastanesi, Gastroenteroloji Kliniği, Ankara, Türkiye

Makalenin Geliş Tarihi: 16.01.2017 Kabul Tarihi: 02.02.2017
Bakteriyel hücre duvarının sentezinin inhibe ederek etki gösterir. Literatürde farelerde teikoplanine bağlı nöbet gelişebileceğini gösteren çalışmalar bulunmasına rağmen (1-3), insanda teikoplanınin indüklediği nöbet vakası bulunmamaktadır. Bu çalışmada, karaciğer nakli sonrası anastomoz darlığı ve takipte kolanjit gelişen bir hastada teikoplanin başlanmasını takiben nöbet gelişen bir olguyu sunuyoruz.

\section{Olgu Sunumu}

Bir buçuk yıl önce kriptojenik karaciğer sirozu nedeniyle karaciğer nakli yapılan 56 yaşında erkek hasta sarılık ve karın ağrısı şikayeti ile dış merkezde acil servise başvurmuş. Hastanın laboratuvar değerlerinde karaciğer fonksiyon testlerinde yükseklik olması üzerine abdominal ultrasonografi çekilmiş. Safra yollarında genişleme tespit edilen hastada anastomoz darlığı düşünülerek 
endoskopik retrograd kolanjiopankreatografi (ERCP) yapılması kararı alınmış ancak yapılamadığından perkütan transhepatik kolonjiografi (PTK) için tarafımıza yönlendirilmiş. Laboratuvar değerlerinde beyaz küre sayısı $5.9 \times 10^{3} / \mathrm{uL}$, C-reaktif protein (CRP) $78 \mathrm{mg} / \mathrm{L}$, aspartat aminotrasferaz (AST) $17 \mathrm{U} / \mathrm{L}, \quad$ alanin transaminaz (ALT) $12 \mathrm{U} / \mathrm{L}$, alkalen fosfataz (ALP) 264 $\mathrm{U} / \mathrm{L}$, gamaglutamil trasferaz (GGT) $90 \mathrm{U} / \mathrm{L}$, total biluribin $3 \mathrm{mg} / \mathrm{dL}$, direkt biluribin $2 \mathrm{mg} / \mathrm{dL}$ ve kronik karaciğer yetmezliğine bağlı serum sodyum değeri $126 \mathrm{mEq} / \mathrm{L}$ saptandı. Fizik muayenede sağ üst kadranda hassasiyet mevcuttu. Hastanemizde hastaya perkütan işlem yapılarak drenaj sağlandı. Kolanjiti olan hastaya imipenem 4x500 mg tedavisi verildi. Karaciğer nakli nedeniyle tacrolimus $2 \mathrm{mg}$ ve ursodeoksikolik asit $1 \mathrm{~g}$ alan hastanın tedavisine devam edildi. İzleminde bilirübin değerleri geriledi ancak ateşi ve beyaz küre değerlerinde yükseklik olması üzerine imipenem tedavisinin 10. gününde tedavisine teikoplanin $2 \times 400 \mathrm{mg}$ yükleme dozunu takiben $1 \times 400 \mathrm{mg}$ eklendi. Bilinen epilepsi hikayesi olmayan hastada ilaç başlandıktan bir gün sonra tonik klonik epileptik nöbetleri oldu. $5 \mathrm{mg}$ diazepam ile nöbeti yatıştı. Nöroloji uzmanının önerisi ile kranial bilgisayarlı tomografi (BT) çekildi. Akut patoloji saptanmadı. Elektrolit bozukluğu için kan değerlerine bakıldı. Siroza bağlı kronik hiponatremik olan hastanın kan sodyum değeri $124 \mathrm{mEg} / \mathrm{L}$ bulundu ve akut hiponatremiyi dışlamak için replasman tedavisi yapıldı. Diğer elektrolitleri normaldi. Ayrıca nöroloji uzmanı tarafından levetiracetam $500 \mathrm{mg} \mathrm{2 \times 1}$ başlandı. Ancak nöbetlerin devam etmesi üzerine elektroensefalografi (EEG) ve kranial magnetik rezonans görüntüleme (MRG) çekildi. EEG normal saptandı. MRG'de ise kronik iskemik değişiklikler saptandı. Sürekli epileptik atakları olan hastada metabolik asidoz gelişti. Levetiracetam dozu arttırımasına rağmen nöbetleri devam eden hasta metabolik asidozu nedeniyle entübe edildi. Hastanın nöbetlerinin teikoplanin hemen başlanmasından sonra başlaması ve diğer etiyolojik faktörlerin dışlanması nedeniyle nöbetlerin teikoplanine bağlı olabileceği düşünüldü ve ilacı sonlandırıldı. İlaç kesilmesi sonrası nöbetler kesildi. Ancak takipte pnömonisi gelişen hasta exitus oldu.

Hastadan tıbbi verilerinin yayınlanabileceğine ilişkin yazılı onam belgesi alındı.

\section{Tartışma}

Epileptik nöbet, beyin disfonksiyonu sonucu ortaya çıkan ani bir davranış değişikliği olarak tanımlanabilir ve nöbetler serebral kortekste nöronal ağların elektriksel aşırı aktivitesinden kaynaklanır (4). Epilepsi öyküsü olmayan hastalar sıklıkla akut tıbbi veya nörolojik hastalık veya yaralanma (inme, travmatik beyin hasarı, menenjit, anoksik ensefalopati, vb.) ortaya çıkması durumunda nöbet geçirirler (5). Nöbetler birçok ilacın yan etkisi olarak da meydana gelebilir. Yeni ortaya çıkmış nöbetlerin \% 6'sının ve status epileptikus vakalarının \% 9'unun ilaçlara ait yan etki olarak ortaya çıktığı tahmin edilmektedir (6). Teikoplanin bir glikopeptid antibiyotiktir ve etki mekanizması ve antibakteriyel spektrumda vankomisine çok benzemektedir. Başta MRSA olmak üzere gram pozitif bakteriyel enfeksiyonda sıklıkla kullanılmaktadır. Bilinen yan etkileri hepatotoksisite, nefrotoksisite, işitme kaybı, agranülositoz olmakla birlikte, intraventriküler uygulamada da nöbet gelişebileceği belirtilmiştir $(1,2)$. Ancak iv uygulama sonrası nöbet gelişimini ilk kez biz bildiriyoruz. Septik ve enfekte ve teikoplanin alan bir hastada nöbet varlığında ilaca bağlı nöbet akılda tutulmalı ve ilaç hemen kesilmelidir.

\section{Kaynaklar}

1. Takechi K, Fujiwara A, Watanabe Y, Kamei C. Participation of GABA-ergic system in epileptogenic activity induced by teicoplanin in mice. Epilepsy Rres 2009;84(2-3):127-34.

2. Takechi K, Ishikawa T, Kamei C. Epileptogenic activity induced by teicoplanin and effects of some antiepileptics in mice. J Pharmacol Sci 2008;107(4):428-33.

3. Rahman MA, Ago J, Matsumoto N, Ishikawa T, Kamei C. Epileptogenic activity of methicillin-resistant Staphylococcus aureus (MRSA) antibiotics in rats. Bio and Pharm Bul 2006;29(10):2035-40.

4. Fisher RS, Acevedo C, Arzimanoglou A, et al. ILAE official report: A practical clinical definition of epilepsy. Epilepsia 2014;55(4):475-82.

5. Beghi E, Carpio A, Forsgren L, et al. Recommendation for a definition of acute symptomatic seizure. Epilepsia 2010;51(4):671-5

6. Pesola GR, Avasarala J. Bupropion seizure proportion among new-onset generalized seizures and drug related seizures presenting to an emergency department. J Emerg Med 2002;22(3):235-9. 